\title{
ANALISA KINERJA KEUANGAN PERUSAHAAN ASURANSI YANG \\ TERDAFTAR DI BURSA EFEK INDONESIA, MALAYSIA DAN \\ THAILAND MENGGUNAKAN ANALISIS RASIO \\ DAN RISK BASED CAPITAL
}

\author{
NGATIMIN \\ Fakultas Ekonomi, Universitas Pamulang \\ ngatimin77@gmail.com
}

\begin{abstract}
To measure financial performance analysis using ratio analysis in accordance with PSAK 28 which consists of Underwriting Ratio, Loss Ratio, Commission Expense Ratio, Liability to Liquid Asset Ratio, Investment to Technical Reserve Ratio, Net Premium Growth, Own Retention Ratio. Parameter used in Indonesia is Risk Based Capital (RBC) in accordance with Decree of Minister of Finance No. 424 / KMK.06 / 2003. The results of the ratio analysis based on the report of annual report are Underwriting Ratio of Indonesia 24.09\%, Malaysia $13.70 \%$ and Thailand 12.22\%, Loss Ratio Indonesia 44.44\%, Malaysia 55.99\% and Thailand $60.05 \%$ Malaysian Revenue Commission 11.53\%, Indonesia 11.99\% and Thailand 19.40\%, Malaysia Liquidity Ratio $83.45 \%$, Indonesia $55.96 \%$ and Thailand $54.42 \%$, Investments to Technical Ratio of Indonesia 685.36\%, Thailand 318.18\% and Malaysia 93.65\%, Net Premium Growth Ratio Indonesia 21.56\%, Malaysia $13.29 \%$ and Thailand $4.42 \%$ and Own Retention Ratio Thailand 851.72\%, Malaysia 79.14\% and Indonesia 72.12\%. While his Risk Base Capital analysis is Thailand 907.58\%, Malaysia 920.68\% and Indonesia 415.07
\end{abstract}

Keywords: Financial Statement, Ratio Analysis, Risk Based Capital

\section{PENDAHULUAN}

Dewasa ini, lembaga asuransi semakin dibutuhkan baik oleh orang pribadi maupun oleh badan usaha. Hal ini disebabkan adanya berbagai risiko yang selalu menyertai dalam setiap aspek kehidupan. Risiko-risiko tersebut tidak dapat dihilangkan ataupun dihindari, namun risiko dapat diminimalkan. Dari berbagai metode yang dapat digunakan, memanfaatkan asuransi adalah merupakan cara yang lazim digunakan untuk meminimalisir risiko yang ada. Asuransi merupakan perjanjian perlindungan kepada pihak tertanggung terhadap kemungkinan timbulnya kerugian.

Kesehatan keuangan sebuah perusahaan asuransi adalah sangat penting, sehingga penilaian atas kesehatan keuangan sangat dibutuhkan untuk memberikan gambaran kinerja asuransi, hal ini berguna bagi kepentingan 
internal, investor, serta bagi pemerintah. Untuk mengawasi terhadap usaha perasuransian pemerintah, telah menerbitkan KMK nomor 424/KMK.06/2003 diantaranya menetapkan besaran persentase minimum Risk Based Capital yang harus taati oleh setiap perusahaan asuransi. Di dalam UU Nomor 2 Tahun 2004 tentang usaha Perasuransian, Batas Risk Based Capital merupakan salah satu cara untuk mengetahui tingkat kesehatan keuangan asuransi.

Perusahaan asuransi yang menuntut capaian laba yang tinggi akan dibatasi oleh ketentuan yang dikeluarkan oleh pemerintah mengenai Risk Based Capital yang harus dicapai oleh perusahaan asuransi. Hal tersebut karena untuk mencapai Batas Tingkat Solvabilitas (Risk Based Capital) perusahaan asuransi kerugian akan mengalami trade off dalam penyerapan risiko, baik risiko underwriting maupun risiko investasi. Untuk mencapai Risk Based Capital yang telah ditetapkan, perusahaan dapat meminimalisir underwritingrisk, dengan cara mengasuransikan kembali sebagian pertanggungan kepada perusahaan asuransi lain atau sering disebut dengan reasuransi. Selain itu, asuransi juga dapat memberikan batasan risiko yang diserap dari pelanggan atau nasabah namun akan ada konsekuensinya yaitu pertumbuhan penerimaan premi akan kursang maksimal atau terbatas. Alternatif lain perusahaan juga dapat mengurangi risiko investasi, bisa dilakukan dengan cara memilih investasi yang tidak terlalu banyak risikonya. Berdasarkan uraian dan latar belakang di atas penulis terdorong untuk melakukan penelitian dengan judul: “Analisis Kinerja Keuangan Perusahaan Asuransi Yang Terdaftar di Bursa Efek Indonesia, Malaysia dan Thailand Menggunakan Analisis Rasio Dan Risk Based Capital". Tujuan penulis melakukan penelitian ini adalah :

1. Untuk mengetahui tingkat kesehatan perusahaan asurasni di Indonesia, Malaysia dan Thailand berdasarkan PSAK no. 28 yaitu dengan menggunakan analisis Underwriting Ratio, Loss Ratio, Commision Expenses Ratio, Liability to Liquid Asset Ratio, Investment to Technical Reserve Ratio, Net Premium Growth, Own Retention Ratio 
2. Untuk mengetahui tingkat solvabilitas perusahaan asuransi berdasarkan KMK Nomor. 424/KMK 06/2003 dengan menggunakan analisis risk based capital.

Hasil penelitian ini di harapkan bisa bermanfaat bagi beberapa pihak antara lain :

\section{Manfaat Teoritis}

Diharapkan dapat memberikan pengetahuan dan wawasan yang terkait Tingkat kesehatan keuangan khususnya di Perusahaan Asuransi masuk Bursa. Selain itu diharapkan dapat bermanfaat bagi dunia pendidikan dan akademisi khususnya untuk menjadi referensi bagi peneliti selanjutnya yang lebih lanjut yang berkaitan dengan masalah ini.

2. Manfaat praktis

Penelitian ini dapat memberikan sumbangan pemikiran bagi Asuransi untuk mengetahui seberapa jauh tingkat kesehatan keuangan Perusahaan Asuransi yang di persyaratkan.

\section{TELAAH LITERATUR DAN PENGEMBANGAN HIPOTESIS}

\section{Pengertian Manajemen}

"Manajemen adalah usaha mencapai suatu tujuan tertentu melalui kegiatan orang lain. Dengan demikian manajer mengadakan koordinasi atas sejumlah aktivitas orang lain yang meliputi perencanaan, pengorganisasian, penggerakan dan pengendalian". Umi Rusilowati, 2013:23.

Sedangkan menurut R. Terry (1994), “Manajemen merupakan suatu proses khas yang terdiri dari tindakan-tindakan perencanaan, pengorganisasian, penggerakan dan pengendalian yang dilakukan untuk menentukan serta mencapai sasaran-sasaran yang telah ditentukan melalui pemanfaatan sumber daya manusia dan sumber-sumber lainnya". Lain lagi dengan pengertian menurut James F. Stoner (1996), "Manajemen adalah proses perencanaan, pengorganisasian dan penggunaan sumber daya-sumber daya organisasi lainnya agar mencapai tujuan organisasi yang telah ditetapkan”. 


\section{Pengertian Manajemen Keuangan}

Perkembangan Manajemen Keuangan mulai dari manajemen yang hanya menitikberatkan aktivitas memperoleh keuangansaja sampai yang menitikberatkan kegiatan mendapatkan dan menggunakan dana serta mengelola terhadap aset. Khusus menganalisa sumber keuangan dan pemanfaatannya untuk mewujudkan keuntungan yang optimal bagi perusahaan . Seorang manajer keuangan harus memahami proses perputaran uang baik didalam maupun di luar perusahaan.

a. Kegiatan Manajemen Keuangan

Manajemen keuangan mempunyai hubungan dengan 3 kegiatan, yaitu:

1) Kegiatan pemanfaatan dana, yaitu kegiatan untuk menanmkan dana pada berbagai Aset. Pengalokasian dana berbentuk selembar kertas berharga atau sering disebut Financial assets (aktiva finansial), misalnya: saham, sertifikat deposito, atau obligasi berupa tanah, bangunan, peralatan yang biasa disebut dengan Real assets (aktiva riil).

2) Kegiatan perolehan dana, yaitu kegiatan untuk menghasilkan sumber dana, baik dari dalam maupun dari luar perusahaan.

3) Kegiatan pengelolaan aset, yaitu setelah mendapatkan dana dan diwujudkan dalam bentuk aset, dana harus dikelola dengan baik.

b. Fungsi Manajemen Keuangan

Berikut ini adalah penjelasan singkat dari fungsi Manajemen Keuangan:

1) Perencanaan Keuangan, membuat rencana baik untuk pendapatan dan pengeluaran dana dalam periode yang sudah ditentukan.

2) Penganggaran Keuangan, merupakan kelanjutan dari perencanaan keuangan dengan membuat daftar pemasukan dan pengeluaran secara rinci.

3) Pengelolaan Keuangan, penggunaan dana untuk kepentingan perusahaan secara maksimal.

4) Pencarian Keuangan, mencari sumber dana yang sekiranya bisa untuk mengoperasikan kegiatan perusahaan. 
5) Penyimpanan Keuangan, perusahaan melakukan penyimpanan untuk mengamankan dana yang ada.

6) Pengendalian Keuangan, melakukan perbaikan dan evaluasi atas pendanaan dan sistem di perusahaan.

7) Pemeriksaan Keuangan, audit internal dilakukan atas penggunaan dana perusahaan yang ada agar tidak terjadi kesalahan dalam realisasi atau penyimpangan.

8) Pelaporan keuangan, kondisi keuangan perusahaan harus di informasikan sebagai bahan evaluasi.

c. Tujuan Manajemen Keuangan

Manajemen Keuangan mempunyai tujuan untuk meningkatkan dari nilai perusahaan. Apabila perusahaan akan dijual, maka nilai atau harga dapat di tetapkan secara maksimal. Manajer juga harus mempunyai kemampuan untuk memberikan tekanan pada arus peredaran uang agar terhindar dari hal hal yang merugikan.

d. Analisis Sumber Dana dan Penggunaannya

Ppertama dalam menganalisa pendapatan dan penggunaan dana adalah laporan perubahan yang dibuat yang didasarkan dua laporan posisi keuangan untuk dua periode. Di dalam laporan tersebut digambarkan perubahan dari masing-masing elemen yang menggambarkan adanya pendapatan atau pemanfatatan dana.

Rasio keuangan yang dianalisa bisa dikelompokkan menjadi enam yaitu :

1) Rasio Likuiditas, rasio ini untuk memberikan gambaran pengukuran kemampuan asuransi untuk memenuhi kewajiban keuangan jangka pendeknya.

2) Rasio Leverage, rasio ini digunakan untuk memberikan gambaran bagaimana mengukur seberapa banyak dana yang di supply oleh pemilik perusahaan dalam proporsinya dengan dana yang didapatkan dari kreditur perusahaan. 
3) Rasio aktivitas, rasio ini digunakan untuk memberikan gambaran pengukuran efektivitas manajemen perusahaan dalam memanfaatkan sumber dayanya.

4) Rasio profitabilitas, rasio ini digunakan untuk menggambarkan pengukuran efektivitas manajemen yang dilihat dari laba yang dihasilkan terhadap penjualan dan investasi perusahaan.

5) Rasio pertumbuhan, rasio ini digunakan untuk memberikan gambaran pengukuran seberapa baik perusahaan mempertahankan posisi ekonominya pertumbuhan ekonomi dan industri.

6) Rasio penilaian, rasio ini merupakan gambaran ukuran capaian prestasi perusahaan paling lengkap, rasio tersebut menggambarkan kombinasi pengaruh dari rasio risiko dengan rasio hasil pengembalian.

\section{Pengertian Asuransi}

Istilah asuransi atau biasa dengan istilah pertanggungan, kedua istilah tersebut merupakan istilah yang ada di dalam Bahasa Belanda yaitu assurantie (asuransi) dan verzekering (pertanggungan), hal ini karena asuransi berasal dari Belanda.

"Asuransi ialah suatu kemauan untuk menetapkan kerugian-kerugian kecil (sedikit) yang sudah pasti sebagai pengganti/substitusi kerugian-kerugian besar yang belum terjadi.” Abbas Salim (2007:1)

Herman Darmawi (2004:2) asuransi dapat dilihat dari bebrapa aspek sudut pandang, yaitu:

a. "Dalam pandangan ekonomi

b. Dalam pandangan hukum

c. Dalam pandangan bisnis

d. Dari sudut pandangan sosial

e. Dari sudut pandang matematika."

Berdasarkan pengertian asuransi diatas dapat disimpulkan bahwa asuransi adalah suatu sarana untuk mengumpulkan risiko yang terdapat pada kegiatan 
ekonomi dengan cara mengumpulkan beberapa unit yang terkena risiko yang sama.

\section{Jenis-jenis Asuransi}

Asuransi dibagi menjadi 2 (dua) bagian, yaitu asuransi rang pribadi atau jiwa dan asuransi harta. Herman Darmawi (2004:26-27) menjelaskan tentang pengertian kedua asuransi tersebut adalah :

1) “Asuransi atas orang (personal insurance), yaitu asuransi yang objeknya orang atau penutupan asuransi atas individu-individu, dengan kata lain adalah asuransi yang berkaitan dengan individu. Adapun risiko yang ditanggung (peril) dalam asuransi atas orang adalah:
a) Kematian
b) Kecelakaan dan sakit
c) Pengangguran, dan
d) Karena umur tua

2) Asuransi atas harta (property insurance), yaitu asuransi yang ditujukan terhadap hal-hal yang mungkin menghancurkan properti atau harta kekayaan. Asuransi ini di Indonesia digolongkan sebagai asuransi kerugian."

\section{Karakteristik Perusahaan Asuransi Kerugian}

Beberapa uraian karakteristik perusahaan asuransi kerugian menurut IAI yang dikeluarkan melalui PSAK No.28 Tahun 2007, adalah sebagai berikut:

a. "Usaha asuransi kerugian merupakan suatu sistem proteksi menghadapi risiko kerugian keuangan dan sekaligus merupakan upaya penghimpunan dana masyarakat.

b. Pertanggungjawaban keuangan kepada para tertanggung mempengaruhi penyajian laporan keuangan.

c. Laporan keuangan sangat dipengaruhi oleh unsur estimasi, misalnya estimasi jumlah premi yang belum merupakan pendapatan (unearned premium), estimasi jumlah klaim, termasuk jumlah klaim yang terjadi 
namun belum dilaporkan (incurred but not reported claims). Dalam menghitung tingkat premi, usaha asuransi kerugian menggunakan asumsi tingkat risiko dan beban.

d. Pihak tertanggung (pembeli asuransi) membayar premi asuransi terlebih dulu kepada perusahaan asuransi sebelum peristiwa yang menimbulkan kerugian yang diperjanjikan terjadi.

e. Jumlah premi yang belum merupakan pendapatan, dan jumlah klaim yang terjadi namun belum dilaporkan, diestimasi dengan menggunakan metode tertentu.

f. Peraturan perundangan dibidang perasuransian mewajibkan perusahaan asuransi kerugian memenuhi ketentuan kesehatan keuangan misalnya tingkat solvabilitas."

\section{Tujuan Asuransi}

Klaim yang diberikan oleh perusahaan asuransi kepada pemegang polis bila pemegang polis menderita kerugian yang dijaminkan oleh polis, bertujuan agar tertanggung bisa kembali seperti sediakala atau untuk pemegang polis dihindarkan dari sebuah kebangkrutan sehingga tertanggung masih bisa tetap eksis.

Dalam penjelasan Radiks Purba (2004:55) asuransi bertujuan sebagai berikut: "Ganti rugi yang diberikan oleh penanggung kepada tertanggung bila tertanggung menderita kerugian yang dijamin oleh polis, bertujuan untuk mengembalikan tertanggung pada posisinya semula, atau untuk menghindarkan tertanggung dari kebangkrutan sehingga ia masih mampu berdiri seperti sebelum menderita kerugian."

Menurut Abbas Salim (2007:29) tujuan asuransi adalah :

a. "Untuk memberikan jaminan perlindungan dari risiko yang diderita suatu pihak.

b. Untuk meningkatkan efisiensi, karena kita tidak perlu secara khusus mengadakan pengamanan dan pengawasan untuk memberikan perlindungan yang memakan banyak tenaga, waktu, dan biaya. 
c. Untuk membantu mengadakan pemerataan biaya, yaitu cukup hanya dengan mengeluarkan biaya untuk premi saja yang jumlahnya sudah tertentu secara tetap perperiode.

d. Untuk dasar pemberian kredit, terutama dalam sistem perkreditan yang dilakukan oleh bank. Bank memerlukan jaminan atau agunan yang diberikan oleh peminjam uang.

e. Sebagai tabungan, bahkan lebih daripada itu karena yang dibayar kepada asuransi akan diterima kembali.

f. Untuk memupuk earning power seseorang, badan usaha yang akan digunakan pada waktu terjadi keadaan dimana ia tidak dapat berfungsi.

g. Untuk modal investasi, bagi pihak lain melalui penggunaan dana yang dikapitalisasi oleh asuransi."

\section{HASIL PENELITIAN DAN PEMBAHASAN}

\section{Analisis Rasio Keuangan}

Analisis rasio keuangan ini terdiri dari Underwriting ratio, Loass ratio, Commision expense ratio, liquidity ratio, invesment to technical ratio, Net premium growth ratio dan Own retention ratio. Dari hasil penelitian analisis rasio keuangan dapat di jelaskan bahwa pada tahun 2011 underwritting ratio perusahaan asuransi Indonesia menempati urutan pertama yaitu 20,62\% kemudian perusahaan asuransi Malaysia 12,70\% dan terakhir perusahaan asuransi Thailand 6,16\%. Tahun 2012 underwritting ratio perusahaan asuransi Indonesia menempati urutan pertama yaitu $22,38 \%$ kemudian perusahaan asuransi Malaysia 13,78\% dan terakhir perusahaan asuransi Thailand 8,48\%. Tahun 2013 underwritting ratio perusahaan asuransi Indonesia menempati urutan pertama yaitu 23,41\% kemudian perusahaan asuransi Thailand 19,90\% dan terakhir perusahaan asuransi Malaysia 14,37\%. Tahun 2014 underwritting ratio perusahaan asuransi Indonesia menempati urutan pertama yaitu 21,15\% kemudian perusahaan asuransi Malaysia 14,56\% dan terakhir perusahaan asuransi Thailand 13,53\%. Tahun 2015 underwritting ratio perusahaan asuransi Indonesia menempati urutan pertama yaitu 22,,50\% kemudian 
perusahaan asuransi Malaysia 13,07\% dan terakhir perusahaan asuransi Thailand 13,03\% Berdasarkan PSAK 28 bahwa under writting ratio dalam kondisi baik apabila hasilnya tidak negatif. Memperkuat penelitian Satria Sulastria (2004:69). menjelaskan “Underwriting ratio menunjukkan tingkat hasil underwriting yang dapat diperoleh perusahaan serta mengukur tingkat keuntungan dari usaha asuransi." Berdasarkan PSAK 28 dan teori Satria sulastria maka underwritting ratio perusahaan asuransi di Indonesia, Malaysia dan Thailand dalam kondisi yang baik.

Loss ratio Pada tahun 2011 perusahaan asuransi Indonesia menempati urutan pertama dengan rasio 44,43\%, kemudian perusahaan asuransi Malaysia 65,97\% dan perusahaan asuransi Thailand 72,79\%. Tahun 2012 perusahaan asuransi Indonesia menempati urutan pertama dengan rasio 43,20\%, kemudian perusahaan asuransi Malaysia $62,77 \%$ dan perusahaan asuransi Thailand 83,77\%. Tahun 2013 perusahaan asuransi Indonesia menempati urutan pertama dengan rasio 44,15\%, kemudian perusahaan asuransi Thailand 49,27\% dan perusahaan asuransi Malaysia 59,20\%. Tahun 2014 perusahaan asuransi Indonesia menempati urutan pertama dengan rasio 45,69\%, kemudian perusahaan asuransi Thailand 48,48\% dan perusahaan asuransi Malaysia 60,60\%. Tahun 2015 perusahaan asuransi Indonesia menempati urutan pertama dengan rasio 44,33\%, kemudian perusahaan asuransi Thailand 46,36\% dan perusahaan asuransi Malaysia 56,26\% Berdasarkan PSAK 28 semakin tinngginya loss ratio mengindikasikan miskinnya underwriting dan menurut Mulyono dalam www.mulyono-tausiyah-blogspot.com menjelaskan bahwa loss ratio $\leq 100 \%$, berarti bahwa premi yang diterima lebih besar dibandingkan dengan klaim yang dibayar. Dari data diatas menunjukkan bahwa perusahaan asuransi Indonesia, perusahaan asuransi Malaysia dan perusahaan asuransi Thailand premi yang di terima lebih besar dari klaim yang dibayar.

Commision expense ratio dari hasil penelitian tahun 2011 perusahaan asuransi Malaysia menempati urutan pertama dengan rasio 12,67\%, kemudian perusahaan asurasni Indonesia 13,07\%, dan terkahir perusahaan asuransi Thailand 20,97\%. Tahun 2012 perusahaan asuransi Indonesia menempati 
urutan pertama dengan rasio 11,61\%, kemudian perusahaan asurasni Malaysia 12,04\%, dan terkahir perusahaan asuransi Thailand 20,30\% . Tahun 2013 perusahaan asuransi Indonesia menempati urutan pertama dengan rasio 10,51\%, kemudian perusahaan asurasni Thailand 19,37\%, dan terkahir perusahaan asuransi Malaysia 73,33\%. Tahun 2014 perusahaan asuransi Malaysia menempati urutan pertama dengan rasio $10,47 \%$, kemudian perusahaan asurasni Indonesia 13,19\%, dan terkahir perusahaan asuransi Thailand 18,71\%. Tahun 2015 perusahaan asuransi Malaysia menempati urutan pertama dengan rasio $10,63 \%$, kemudian perusahaan asurasni Indonesia 11,58\%, dan terkahir perusahaan asuransi Thailand 17,63\%. Berdasarkan PSAK 28 bahwa semakin tinggi rasionya menunjukkan bahwa perusahan asuransi makin banyak memberikan komisi kepada agen atau broker.

Liability to liquid assets ratio dari hasil penelitian tahun 2011 perusahaan asurasni Indonesia menempati urutan pertama dengan rasio 52,77\%, kemudian perusahaan asuransi Thailand 64,80\% dan perusahaan asuransi Malaysia 86,39\%. Tahun 2012 perusahaan asurasni Indonesia menempati urutan pertama dengan rasio 51,05\%, kemudian perusahaan asuransi Thailand 59,66\% dan perusahaan asuransi Malaysia 82,29\%. Tahun 2013 perusahaan asurasni Thailand menempati urutan pertama dengan rasio 57,26\%, kemudian perusahaan asuransi Indonesia 59,30\% dan perusahaan asuransi Malaysia 73,33\%. Tahun 2014 perusahaan asurasni Thailand menempati urutan pertama dengan rasio 47,79\%, kemudian perusahaan asuransi Indonesia 58,45\% dan perusahaan asuransi Malaysia 83,26\%. Tahun 2015 perusahaan asurasni Thailand menempati urutan pertama dengan rasio 42,60\%, kemudian perusahaan asuransi Indonesia 58,22\% dan perusahaan asuransi Malaysia 82,36\%. Berdasarkan PSAK 28 bahwa semakin tingginya rasio likuidiats menunjukkan kemampuan perusahaan dalam menghandel kewajibannya semakin rendah, maka perusahaan asuransi yang bagus rasionya adalan perusahaan asuransi Indonesia dan perusahaan asuransi Thailand dibandingkan perusahaan asuransi Malaysia. 
Investment to technical ratio dari hasil penelitian tahun 2011 perusahaan asuransi negara Indonesia menempati urutan pertama dengan rasio 283,59\%, disusul perusahaan asuransi Thailand 87,69\% kemudian perusahaan asuransi Malaysia 65,27\%. Tahun 2012 perusahaan asuransi negara Indonesia menempati urutan pertama dengan rasio $635,41 \%$, disusul perusahaan asuransi Thailand 117,78\% kemudian perusahaan asuransi Malaysia 102,48\%. Tahun 2013 perusahaan asuransi negara Indonesia menempati urutan pertama dengan rasio $444,85 \%$, disusul perusahaan asuransi Thailand 230,91\% kemudian perusahaan asuransi Malaysia 73,33\%. Tahun 2014 perusahaan asuransi negara Indonesia menempati urutan pertama dengan rasio $1539,51 \%$, disusul perusahaan asuransi Thailand 473,68\% kemudian perusahaan asuransi Malaysia 95,43\%. Tahun 2015 perusahaan asuransi negara Thailand menempati urutan pertama dengan rasio $680,84 \%$, disusul perusahaan asuransi Indonesia 523,45\% kemudian perusahaan asuransi Malaysia 101,59\%. Berdasarkan PSAK 28 bahwa semakin rendahnya Investment to Technical Reserve Ratio mengindikasikan bahwa estimasi klaim tanggungan kurang di dukung dengan dana yang memadai. Dari data diatas menunjukkan bahwa perusahaan asuransi Indonesia paling bagus kemudian perusahaan asuransi Thailand dan perusahaan asuransi Malaysia rasionya tidak bagus.

Net premium growth ratio dari hasil penelitian perusahaan asuransi Indonesia 21,56\%, perusahaan asuransi Malaysia 13,29\% dan perusahaan asuransi Thailand 4,42\%. Berdasarkan PSAK 28 apabila terjadi kenaikan atau penurunan yang tajam mengindikasikan bahwa kurangnya kestabilan operasi perusahaan. Dari data diatas menunjukkan bahwa perusahaan asuransi Thailand paling stabil operasionalnya kemudian perusahaan asurasnsi Malaysia dan yang paling tidak stabil operasionalnya dalam penelitian ini adalah perusahaan asuransii Indonesia yaitu dengan rasio 21,56\%.

Own retention ratio dari hasil penelitian tahun 2011 perusahaan asuransi Indonesia menempati urutan pertama dengan rasio 69,92\%, kemudian perusahaan asuransi Malaysia 77,58\% dan perusahaan asuransi Thailand 1622,20\%. Tahun 2012 perusahaan asuransi Indonesia menempati urutan 
pertama dengan rasio 71,30\%, kemudian perusahaan asuransi Malaysia 75,33\% dan perusahaan asuransi Thailand 1178,73\%. Tahun 2013 perusahaan asuransi Indonesia menempati urutan pertama dengan rasio 74,63\%, kemudian perusahaan asuransi Malaysia 73,33\% dan perusahaan asuransi Thailand 502,53\%. Tahun 2014 perusahaan asuransi Indonesia menempati urutan pertama dengan rasio 73,58\%, kemudian perusahaan asuransi Malaysia 74,29\% dan perusahaan asuransi Thailand 522,84\%. Tahun 2015 perusahaan asuransi Indonesia menempati urutan pertama dengan rasio $71,20 \%$, kemudian perusahaan asuransi Malaysia 92,86\% dan perusahaan asuransi Thailand 432,29\%. Berdasarkan PSAK 28 semakin tingginya Own Retention Ratio mengindikasikan bahwa tingkat retensi atau kesuliatan perusahaan asuransi semakin tinggi. Dari data diatas menunjukkan bahwa retensi paling tinggi di tunjukkan oleh perusahaan asuransi Thailand dengan rasio $851,72 \%$ kemudian perusahaan asuransi Malaysia 79,14\% dan paling rendah retensinya adalah perusahaan asuransi Indonesia dengan rasio $72,12 \%$.

\section{Risk based capital}

Berdasarkan penelitian dapat diperoleh hasil bahwa tahun 2011 risk basd capital perusahaan asuransi Malaysia $1513,46 \%$, di susul perusahaan asuransi Thailand 891,22\% dan perusahaan asuransi Indonesia 369,29\%. Tahun 2012 perusahaan asuransi Malaysia 876,67\%, di susul perusahaan asuransi Thailand $731,59 \%$ dan perusahaan asuransi Indonesia 460,57\%. Tahun 2013 perusahaan asuransi Thailand 926,84\%, di susul perusahaan asuransi Malaysia 820,76\% dan perusahaan asuransi Indonesia 425,03\%. Tahun 2014 perusahaan asuransi Thailand 927,86\%, di susul perusahaan asuransi Malaysia 598,42\% dan perusahaan asuransi Indonesia 404,94\%. Tahun 2015 perusahaan asuransi Thailand 1060,41\%, di susul perusahaan asuransi Malaysia 694,08\% dan perusahaan asuransi Indonesia 415,54\%. Berdasarkan hasil penelitian diatas menurut KMK/424.06/2003 dan hasil penelitian Sindi Nurfadila, Raden Rustam Hidayat Sri Sulasmiyati Fakultas Ilmu Administrasi Universitas Brawijaya Malang bahwa batas solvabilitas yang di ukur dengan metode risk 
based capital adalah 120\% sehingga dari hasil penelitian menunjukkan bawa perusahaan asuransi di Indonesia, Malaysia dan Thailand solvabilitasnya bagus karena masih diatas ambang batas yang di perkenankan yaitu $120 \%$.

\section{KESIMPULAN}

Dari hasil analisis dapat di simpulkan yaitu :

1. Perbandingan hasil pengukuran kinerja keuangan perusahaan asuransi yang terdaftar di bursa efek Indonesia, Malaysia dan Thailand menggunakan analisis rasio adalah sebagai berikut : Underwriting Ratio Indonesia 24,09\%, Malaysia 13,70\% dan Thailand 12,22\%, Loss Ratio Indonesia 44,44\%, Malaysia 55,99\% dan Thailand 60,05\%, Commision Expense Ratio Malaysia 11,53\%, Indonesia 11,99\% dan Thailand 19,40\%, Liability to liquid assets ratio Malaysia 83,45\%, Indonesia 55,96\% dan Thailand 54,42\%, Invesment to Technical Ratio Indonesia 685,36\%, Thailand 318,18\% dan Malaysia 93,65\%, Net Premium Growth Ratio Indonesia 21,56\%, Malaysia 13,29\% dan Thailand 4,42\% dan Own Retention Ratio Thailand 851,72\%, Malaysia 79,14\% dan Indonesia 72,12\%. Dari perbandingan ini dapat di jelaskan bahwa rasio keuangan terbaik adalah perusahaan asuransiIndonesia di susul berikutnya adalah perusahaan asuransi Malaysia dan yang terakhir adalah perusahaan asuransi Thailand.

2. Perbandingan hasil pengukuran kinerja keuangan perusahaan asuransi yang terdaftar di bursa efek Indonesia, Malaysia dan Thailand menggunakan analisis Risk Base Capital adalah sebagai berikut : perusahaan asuransi Malaysia 920,68\%, perusahaan asuransi Thailand 907,58\%, dan perusahaan asuransi Indonesia 415,07\%. Dari perbandingan ini dapat di jelaskan bahwa Risk Base Capital terbaik di peroleh perusahaan asuransi Malaysia di susul perusahaan asuransi Thailand dan terakhir perusahaan asuransi Indonesia, namun dari rasio yang ada pada dasarnya masih berada di atas ambang batas yang di persyaratkan oleh KMK No. 424/KMK.06/2003 pasal 2 ayat 1 yaitu $120 \%$. 


\section{Saran}

1. Meningkatkan jumlah nasabah sehingga penerimaan premi naik, karena premi merupakan faktor utama kesehatan sebuah asurasni.

2. Memperbaiki kinerja keuangan agar menarik para investor untuk menanamkan modalnya di perusahaan asuransi sehingga bisa meningkatkan Risk Based Capital

3. Penelitian ini menggunakan sample di kawasan Asia Tenggara, kedepan akan lenih baik lagi penelitian di lakukan lebih banyak samplenya dan bisa mengambil dari belahan dunia di luar Asia Tenggara agar terjadi perbandingan yang bisa di jadikan acuan untuk perkembangan perusahaan asuransi dan reasuransi dalam negeri.

\section{REFERENSI}

Abbas Salim. 2007. Asuransi dan Manajemen. Jakarta: Raja Grafindo Persada. Annual Report Bursa Efek Indonesia, Malaysia dan Thailand tahun 2011-2015. Darmawi, Herman. 2004. Manajemen Asuransi. Jakarta: PT Bumi Aksara.

James F. Stoner, dkk. 1996. Manajemen, Edisi Indonesia. Jakarta: PT Prenhallindo.

Keputusan Menteri Keuangan Nomomr 424/KMK.06/2003

PSAK no. 28 tahun 2007

Radiks Purba. 2004. Asuransi Indonesia. Jakarta: Salemba Empat.

Rusilowati, Umi. “ Manajemen Pengetahuan Berbasis Teknologi Informasi Dalam Konteks Pembelajaran Organisasi" Penerbit Asmoro Mediatama Pamulang. Tangerang Selatan, 2013

Terry, George R. 1994. Dasar-dasar Manajemen. Jakarta: PT Bumi Aksara UU Nomor 2 Tahun 2004 Tentang Usaha Perasuransian 